San Jose State University

SJSU ScholarWorks

Master's Theses

Master's Theses and Graduate Research

1989

\title{
Elements of a model of a multi-party political system in its social context
}

Edgar Emanuel Azevedo

San Jose State University

Follow this and additional works at: https://scholarworks.sjsu.edu/etd_theses

\section{Recommended Citation}

Azevedo, Edgar Emanuel, "Elements of a model of a multi-party political system in its social context" (1989). Master's Theses. 3122.

DOI: https://doi.org/10.31979/etd.97dp-g49p

https://scholarworks.sjsu.edu/etd_theses/3122

This Thesis is brought to you for free and open access by the Master's Theses and Graduate Research at SJSU ScholarWorks. It has been accepted for inclusion in Master's Theses by an authorized administrator of SJSU ScholarWorks. For more information, please contact scholarworks@sjsu.edu. 


\section{INFORMATION TO USERS}

The most advanced technology has been used to photograph and reproduce this manuscript from the microfilm master. UMI films the text directly from the original or copy submitted. Thus, some thesis and dissertation copies are in typewriter face, while others may be from any type of computer printer.

The quality of this reproduction is dependent upon the quality of the copy submitted. Broken or indistinct print, colored or poor quality illustrations and photographs, print bleedthrough, substandard margins, and improper alignment can adversely affect reproduction.

In the unlikely event that the author did not sent UMI a complete manuscript and there are missing pages, these will be noted. Also, if unauthorized copyright material had to be removed, a note will indicate the deletion.

Oversize materials (e.g., maps, drawings, charts) are reproduced by sectioning the original, beginning at the upper left-hand corner and continuing from left to right in photographed in one exposure and is included in reduced form at the back of the book.

Photographs included in the original manuscript have been reproduced xerographically in this copy. Higher quality $6 " \times 9$ " black and white photographic prints are available for any photographs or illustrations appearing in this copy for an additional charge. Contact UMI directly to order.

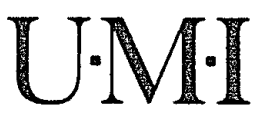



Order Number 1938675

Elements of a model of a multi-party political system in its social context

Azevedo, Edgar Emanuel, M.A.

San Jose State University, 1989 



\title{
ELEMENTS OF A MODEL OF A MULTI-PARTY POLITICAL SYSTEM IN ITS SOCIAL CONTEXT
}

\author{
A Thesis \\ Presented to \\ The Faculty of the Department of Political Science \\ San Jose State University
}

In Partial Fulfillment

of the Requirements for the Degree

Master of Arts

By

Edgar Emanuel Azevedo

May, 1989 


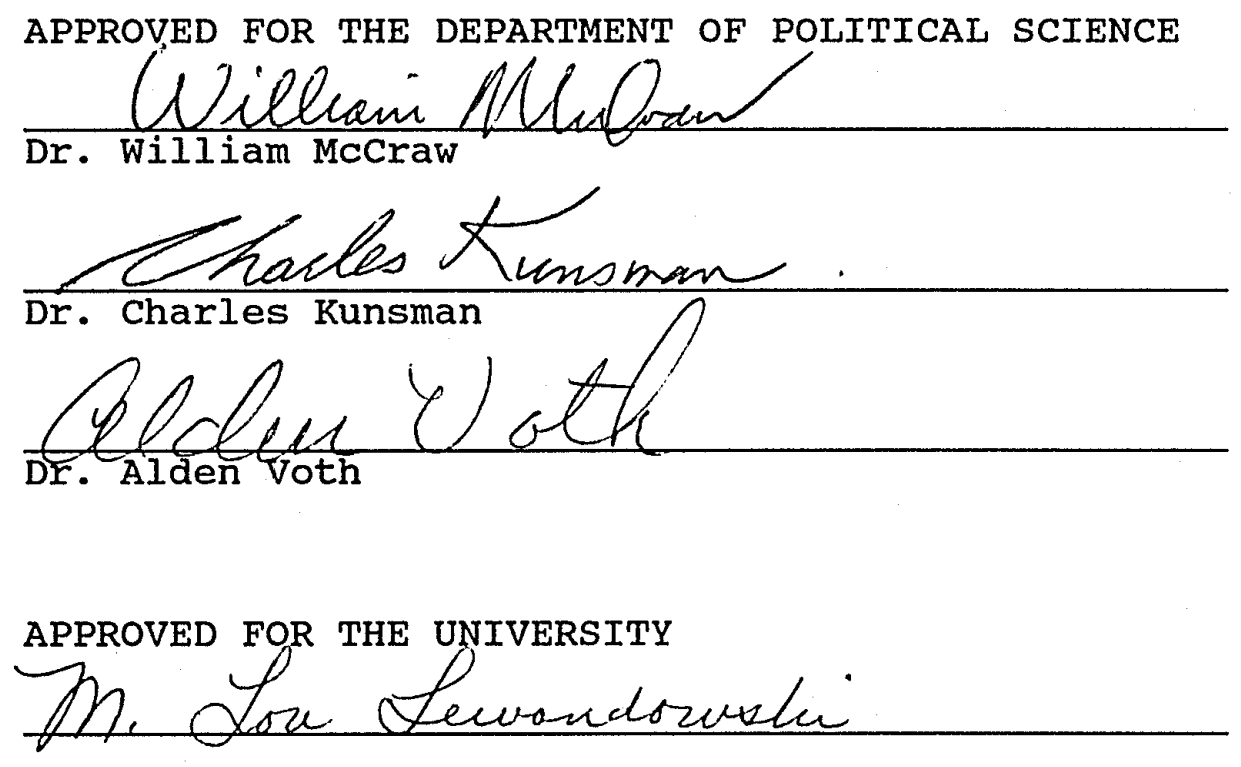




\section{ABSTRACT \\ ELEMENTS OF A MODEL OF A MULTI-PARTY POLITICAL SYSTEM IN ITS SOCIAL CONTEXT \\ by Edgar E. Azevedo}

This thesis is an attempt to establish a model of a multi-party political system in its social context. This particular model allows for the analysis of all important elements in the generic definition of a political party. Procedural methods, power, organization, internal conflicts, financial support, and the political system itself are part of this dynamic universe.

An attentive look on this subject shows that the political party reality in a multi-party system cannot be captured by a rigid and conclusive model, for most things are perceived as a flowing conflict of interests.

Many conclusions are reached in this study, although emphasis is not placed on them, but rather on all the important relations established by elements that surround them and ultimately shape them. 
TABLE OF CONTENTS

PREFACE

iii

CHAPTER

I. ENDOGENOUS FACTORS . . . . . . . . . . . . . 1

The Use of Political Means of Action

and Expression . . . . . . . . . . . . . 1

The Function of Political Representation . . 9

The Function of Political Expression . . . . 14

The Multidimensional organization . . . . . 19

The Variable in the Formula of Distribution

of Political Power . . . . . . . . . . 25

The Center of Political Decision . . . . . 29

The Function of Political Domination . . . 36

The Function of Political orientation . . . 45

The Network of Internal Conflicts . . . . . 50

The Difference of status as the Political

Identity ...... . . . . . . . . 55

II. EXOGENOUS FACTORS . . . . . . . . . . . 60

The Network of Relations Among Political

Parties ................. . 62

The Network of Relations with the organs

of Sovereignty .. . . . . . . . . . 64

The Relativity of the Position of the Political Party . . . . . . . . . . . .

The Relativity of Possibilities in the

Political System . . . . . . . . . . . 69

The Strategic Production . . . . . . . . 71

The Production of Political Conceptions . . 75

Financial support . . . . . . . . . . 79 
III. CONCLUSION . . . . . . . . . . . . . . . 83

BIBLIOGRAPHY • . . . . . . . . . . . . . . . . . ${ }^{84}$ 


\section{PREFACE}

It is the purpose of this thesis to attempt to conceive a model of observation of a multi-party political system in its social context. Relevance is given to the definition of the concept of "political party" and to the evolution of the same subject, as it is an indispensable instrument of political action.

The model in question consists of the finding of basic notions that give content to a multi-party political reality: its multiplicity of elements, its internal procedures, and the critical points of its conception and functioning. This model allows for the observation of the political party, rapidly changing into the political party system without confusing concepts, though the spectrum of analysis becomes more fluid and broadened.

Instead of underlining the point of view of practical party intervention in well-defined situations, the chosen model emphasizes the theoretical aspects of the political party. It indicates that no intervention is consistent without a theoretical support that determines the interests of the political party.

Many authors referred to the necessity of a model having all relevant characteristics for the different theoretical interpretations. Its justification and 
consistency would remain in the fact that, as a whole or in its parts, the model cannot be refuted by any of those theoretical positions. However, the model at hand, like any other model, can only show us so much. Other models, on the other hand, would possibly allow us to perceive other things. It would therefore be incorrect to consider the present model as the only possible model. 
CHAPTER I

\section{ENDOGENOUS FACTORS}

As happens with any other entity in the social system, the political party has an internal reality which is a factor of consistency and of identity. Both, being means of differentiation from other similar entities in the social system, are also restrictive of its way of action. The basic characteristics of existence of the political party, will be designated as endogenous factors. The Use of Political Means of Action and Expression

This is a primary level of analysis, a rather common factor of definition that aims to identify the reality of the political party. Marcelo Rebelo de Sousa has said that: "A political party is an organization, distinctive from other organizations in its objective of intervention in the political system." 1 The existence of an objective makes natural the possession of means with which to intervene in the political field. These means of action are to be defined as political. However, reflection will show that this notion of the political party is insufficient to distinguish the political party from any other social organization.

${ }^{2}$ Marcelo Rebelo de Sousa, "Os Partidos Politicos na Constituição," Estudos de Direito Constitucional, 2nd ed., (Faculdade de Direito da Universidade de Lisboa, 1980), p. 61. Author's translation. 
So far, this definition makes it only possible to distinguish the political party from such other complex organizations as the corporation, the museum, or the university. By being too general, this definition does not allow making precise distinctions. What then distinguishes a political party from a pressure group, which also shares the objective of political intervention? Both organizations act in the same system and use political means in their activities.

The singularity of the political party is therefore not thoroughly defined by the description of its objectives, encouraging the belief that the similarity of objectives can be common to other organizations, even though they cannot be classified as political parties. The uniqueness of the political party is also not determined by the type of formal organization by which the political party finds itself structured. The president or the general secretary of the political party cannot accept being identified as the administrator of an enterprise, as does the curator of the museum or the dean of the university. Nothing says that prominent members of the political party and masses alike are to be identified in the same ways as are workers, technicians, art dealers, janitors, or professors. 
There are not many forms of organizing collective work that can be expected to have a specific form of organization that apply exclusively to the political party. Essential to the political party, then, is simply being an organization in the political system, conjunctively with other organizations. It is impossible to speak of the political party without understanding it as a structure. The political party is a way of organizing collective activities. Although this factor obviously still does not constitute a differentiating element in relation to other entities, either as an object or a type of organization, it remains in itself a condition of the existence of political parties.

There is no political party where there is no organization. This makes it easier to understand that the political party with a flawed organization can be used or controlled by other more efficient and sophisticated organizations that are seeking certain political ends. This line of reasoning is especially important in political regimes where intervention in the political system and the use of political means are closely associated with or reserved to the political parties.

The vulnerability of the political party organization makes it susceptible to forms of dependency on other 
organizations, including infiltration. Under these circumstances, not even the monopoly of the political means of action is enough indication of the autonomy of the political party. In a way, the political party could prove itself an empty organization, permeated by other decisionmakers who are not part of its structure.

In order to be able to perform satisfactorily in the political system, the political party organization needs to be complex in its structure, to the extent that the diversity of its functions requires. Otherwise, it becomes a vulnerable organization, open to any excessive simplification of its complexity that would allow for dependency or infiltration, thus emptying or neutralizing it, and making captives of its legitimately selected decision-makers. Once this happens, it is with great difficulty that an organization can assimilate or reject the alien influence; more frequently it finds itself adapting, and therefore accepting the resulting deformation of procedure and content.

The aspect of organization can never be regarded as of secondary importance. In many instances, what appears to be globally understood as a critique of the action of the political party is no more than a critique of its structure and its organization for the continuous sustaining of its 
work. In such criticisms the decision-making procedure can be seen as is a priori vitiated, even before issues reach the proper hierarchical levels. Here, the reverse tendency shows itself, in the growing dependency of the decisionmakers, as what they themselves are capable of producing when interpreting and analyzing possibilities and proposals. In other words, the organizational structure collapses, and decisions become personalized and arbitrary, lacking collective content.

If the political party is to be perceived as an ordered structure of functions and powers, having as an objective the preparation and execution of activities, it is to be expected that such ordination allows for the option of choice between alternatives, taken within a hierarchical structure. In that case, it is not a simple distributive organization, but a productive organization with the capacity to intervene in the political system. The internal functional divisions of this organization should correspond to areas of real or potential action that may be incorporated naturally into its political activity. The hierarchical problem within the political party can find many different solutions, as is the case with any other organization: "It can be centralized or decentralized, specialized by sectors or of a general nature, vertical or 
matricial." 2 It cannot, however, be nonexistent, substituted for, or overlap the functional divisions within the political party.

The right to leadership or power can be used only in accordance with the means that enable it to be translated into action and facts. Power implies that the means of command have always an organizational component and do not exist without it. Consider, for instance, that no dictatorial power has its affirmation only in the central figure of the dictator; in fact, it exists only because there is a functional organization that creates the effect of the idiosyncratic personality extended to all areas of politics. The same line of thought is also true in a democracy, where the refusal to use authoritarian methods imposes the necessity of solving the organizational problems through decisions in which there is collective participation.

There is an inevitable tension between the affirmation of the hierarchy inside the political party and the need to construct and make the internal functional divisions operational. The question here is not the legitimacy of the political party's hierarchy, which is assumed to have been

\footnotetext{
2José Morgado, "As eleiçoẽs, a CDU e a Doutrina da bipolarização," Diário de Noticias (Lisbon), 26 June 1987, p. 7. Author's translation.
} 
chosen by general consent and within party regulations, but as to the capacity of that hierarchy properly to run the political party, in order to achieve its objective, namely, intervention in the political system. There is a similar situation in the organization of enterprises:

No one doubts that the entrepreneur wants to reach certain objectives. The real problem remains in whether or not he has the capacity to lead his organization to effectively attain those goals. ${ }^{3}$

In the political hierarchy, the problem lies in establishing an articulation with its internal functional divisions, in such a way as to maintain its relevance, their cooperation, and the party's ability to respond to opportunities within the political party system in which these decision-makers preserve their powers. A hierarchy with its own procedural methods, relevance, and internal functional divisions can be understood as a form of strategy.

The conception of an organization is closely related to the field of action toward which it is directed. The organizational format chosen is, at the same time, a statement about the political system (bearing in mind that it was structured to adjust to the opportunity to respond to any problems within the system), and it is a strategy for

\footnotetext{
${ }^{3}$ Antonio Soares Barata, "Função Empresarial na Sociedade," in Estudos de Ciencias Sociais, 2nd ed., (Porto Editora, 1976), p. 34. Author's translation.
} 
the kind of intervention that threatens to develop. Although this may appear rather evident, its consequences within the political system are not easily recognized. No entrepreneur with good sense and a sound notion of risk would structure his enterprise as a direct imitation of what appeared in other enterprises and in other economic systems. On the contrary, what might account for his success is his discerning judgment in determining which organizational form is compatible with the economic system in question. There is a direct relation between the success of an organization and the specificity of elements in the system in its acts. There is no reason to believe that this reasoning does not apply to the political party, which is also an organization forced to adjust to a defined space of action. The relation is in the way the political party organizes itself and the perception of the political system in which it undertakes its activity. It is not enough to evaluate the political party by its organization, just as it also is not enough to describe the political party solely on the basis of the concept of the organization. It is, nevertheless, already feasible to reach the conclusion that the study of the political party's organization provides important elements for defining and evaluating it as an 
entity with the preparation for the purpose of intervening into the political system.

The Function of Political Representation

The political party is an organization with the means and expectation of intervening in the political system. It is essential to define what is exceptional in its origin and structure which gives it this status, and at the same time denies it, at least formally, to other organizations. other social entities, perhaps endowed with more sophisticated organizational structures and better preparation for the analysis of social problems, can perform political tasks only through the protection of multiple disguises or, whenever possible, through the political parties themselves. Take for instance social, political, and monetary associations.

After identifying where the right to enter the political arena originates, an essential characteristic of the concept of political party is ascertained, confirming at the same time its relations of cooperation, competition, or conflict with other types of organizations.

This grasp will also prove itself of great importance in the selection of an organizational format which is possible and adequate for the fulfillment of the party's implicit objectives. As Maria G. Lourenço has written, 
In abstract terms, a lesser amount of organizational rationality could be the price to pay for what the party has of specificity, that which enables it to act where other organizations, perhaps less efficient and more rationalized, cannot without having to pay a price high enough to annihilate their large rationality and efficiency. 4

originally, the political party represented collective social interests: existing social groups with selfinterests and ends. It was through the political party that an organized connection was created, making it become responsible to both other social groups and the political system. Wherever there is no recognition of the existence of social groups with separate interests and different goals, there is no place for political parties, simply because no value at all is attributed to their function of representation. The same can be said for political systems where it is agreed that only one point of representation can express all social interests. Defined as such, the existence of the political party is not independent of the recognition that society is constituted of different social groups. The necessary relation between the political party and these social groups serves so that this recognition may have a practical meaning. The acceptance of social

${ }^{4}$ Maria G. Lourenço, "Concepções diferentes de Sociedade separam Freitas de Pintasilgo," Diário de Noticias (Lisbon), 27 December 1985, p. 11. Author's translation. 
pluralisin must correspond to the recognition of political pluralism and the multi-party or bi-party system; this is a way of justifying democratic pluralism, which, at the same time, does away with the need for recourse to any ideological justifications.

The political party has in its origin an element of social reference and temporal. continuity (by not being a mere imaginary construction and not having only conjectural goals), becoming, therefore, a product of a dual relation. on the one hand, there is the specific organization, one which represents the social interests that remain at the heart of the political party's origin. The social interests cannot have a consistent, and continuous, political status without a specific form of organization, the political party, directed to act in the political system. On the other hand, the action taken by the political party in the political system is not independent of the capacity that the political party has to communicate in the name of the social groups that it represents and of bringing to life their goals. Without this dual connection, it would cease to exist. In this situation, the consequences would be that the social groups' transference would not be processed immediately, creating factors of distortion: the presence of the political party divested of content in the political 
system, and the existence of the social groups without political representation. Political situations where the transfer of the power of representation is gradual and where, subsequently, lack of adjustment in the relationship of representation takes place, lead to the increase of instability in the political system.

These are two sides to the service of representation rendered by the political party, that, at the same time, assures the presence of social groups in the political system. By being a general condition of the existence of the political party with a social reference, and a temporal continuity, the service of representation gives to the political party its real content and also its structural condition for stability.

This factor of the analysis of the political party is important in determining the conditions of the political organization and of the political party's action. Especially, it shows that the political party hierarchy, the exercise of its functions and of its decision-making, is not the exclusive property of the political party. The number of options taken by the hierarchy, already constricted by way of the internal functioning of the organization, is now limited by the service of representation, which ought to be assured. 
This is one of the crucial problems, perhaps even an insoluble one, of today's political parties which intend to have multiple representation of different social interests. It is a classical problem constantly present in the exercise of power in a multi-party or bi-party system. One of the intrinsic functions of the exercise of executive power is exactly the control of levels of conflict established among different social interests that dispute the distribution of social benefits. The function of governing, however, does not restrict itself to a specific function of representation. Its normal objective is to achieve a stable balance among the different functions of representation that correspond to various social interests and to orient this multiplicity of interests towards a common direction. While this integration within the political party is accepted as expressing its function of representation, in the worst case there may be found a confusion of political functions that will not lead to achieving any of those goals.

In practice, the expectation of the performance of multiple representation of different social interests may be an incentive for an equivocation of representation, facilitating the conquest of an upcoming election at the cost of losing flexibility and innovation in performing the functions of government. The final result of this is 
usually reflected in the succeeding election. The general alienation of the social groups that expected to be represented by the political party will provoke, simultaneously, its defeat and emptiness in the area of social representation.

The path to electoral victory by this ambiguous method of multiple representation may therefore contain a direct menace to the existence of the political party that, in any case, may increase instability in the political system.

In contemporary political situations, where the notion of class has lost part of its political operationality, each political party is a contender for the representation of a series of connected social groups. Each political party has an internal coalition of social interests, that, although different, are still compatible, in order to unify its action.

The Function of Political Expression

The political representation of social interests is related to the expression of these same interests in specific political conceptions. The act of representation by the political party, mediating between the social system and the political system, is the presentation of the political content of these social interests. In this way, the political party establishes a new service, the 
rationalization of the interests, behaviors, and objectives of the social groups, which implies that the political party has its own function and is not merely a direct reflection of the spontaneous positions of social groups. The function of political expression is a counterpart to the limitation of the political party's liberty, inherent in its service of representation, and, at the same time, to the limits of the social groups, since they do not have political existence; translation of their interests can only be by the political party.

The function of the political expression of social groups is vital to the viability of the social system and constitutes, in itself, one of the necessary ingredients of the political system. otherwise, the direct expression of social interests would easily lead to conflicting situations, whose solution would lead one step further into the path of overt confrontation.

It is obvious that the existence of political parties per se does not eradicate the factors of contradiction or antagonism, a reality among social groups. On the other hand, it is one of their functions to allow for a rationalization of these social positions (in search of possible solutions and general satisfaction), and also for the mediation of potential conflicts between rival 
interests, in preventing them from being directly established among the social groups themselves and between them and the political system. To some extent, a substantial part of the conflicts among political parties can be perceived as a substitution process or a controlled projection of what could be a violent social confrontation, where if not for a mediating action among the political parties, among the social groups, and between them and the political system, the violence would become rampant.

The action taken by the political party in the function of representation and expression of social interests is neither passive nor simply reflexive. The function of rationalization related to political expression is always active, while the function of representation, in order to increase its capacity to influence, is dynamic and tends to extend and ally itself to other social areas.

Further, political party action is not of an autonomous nature. The political party that determines its own actions solely in accordance with its own reasons, without taking into consideration the social interests that supposedly it represents, is at risk of permanent annihilation. This may explain why sometimes the convenient strategy delineated by the political party hierarchy does not correspond to the convenient party entity necessary to its continuity. The 
political party's choice of direction, regarded as one guided by consideration of the conquest of power, can easily be influenced by the demonstration of results gained by its leadership, but the political party itself is always dependent on the quality of the services of representation and of the expression of social interests, thereby justifying its existence. The degree of autonomy achieved by a political party reflects the quality of the services it performs. Sometimes, to ensure the quality of services, the political party hierarchy finds itself forced to lose some freedom of action and eventually to reject possibilities of action that could offer prospects for the conquest of, or direct participation in, power.

The functions of political representation and of political expression cannot be guaranteed by an isolated personality, meaning that there is no value in the existence of a political party personalized in a political agent alone. The need for an organization is reiterated. There are no personal political parties. There are only political parties endowed with organization, hierarchy, and functional divisions that establish a permanent link with social groups. They are necessarily collective structures with the dynamic support of social movements. 
For identical reasons, the attempt to turn the state into an organized complex that could substitute for the political party at the service of a personality is always threatened by the inevitable rupture of the state's function. It is true that the state is endowed with the organization, the means, and the capacity to achieve political ends, but it is impossible for it to represent and to express at the same time the interests of all social groups in that unique organizational structure. Consequently, in such an attempt, the strength concentrated in the state, and the lack of mediation between social groups would be sufficient to bring about dysfunction and, eventually, rupture. The moment of rupture can be delayed, however, by the use of distributive artifices and by the internal dynamism of the social system. It cannot, however, be avoided, and the certainty of inevitable rupture makes merging the state and the political party inherently unstable, for the advantages eventually conceded to some social groups will be destroyed by the process that leads to the state's breakdown and by the events that follow. The functions of political representation and of political expression are vital to the viability of the social system, just as they are of inestimable importance to the existence and continuity of the political parties. 
Beyond the primary level of their social manifestations, these differences among social groups, unless mediated, could lead to violence at first and, later on, to the rule of the strongest; indeed, conflict over which group is the strongest could resume the path of violence. To avoid this oscillation and destructive process, liberal societies approach and solve the political problem with pluralism centering on the existence of the political parties that represent and express differences among social groups. However, this is still not a definite solution. There is no guarantee that, if the political parties fail in mediation, this will not bring back the return of violence. The democratic path is narrow and more unstable than most political parties would like to admit. The Multidimensional organization

There is a necessary relationship between the political party and the political system. If understood as a simple relation, it is not different in principle from that established between the economic enterprise and the economic system.

The political system and the political party are different concepts. The notion of the political system is obviously ampler and far more general than the idea of the political party. Nevertheless, both notions coincide in the 
area of action, and that is an important point to take into account.

No political party can afford the lack of a stand towards any political problem; it cannot, as well, refuse to assume the responsibilities of power entrusted to it. An attitude of renunciation towards any of these generic functions would imply either the demise of the political party or, at least, its loss of relevance as an active entity in the political system.

Because the political system is of a multidimensional nature, it is understandable that the political party has to show a similar purpose and therefore a similar multidimensionality in its action. The term multidimensionality represents a diversity of problems that need to be resolved at multiple social levels, and which deals with issues concerning the economy, culture, health, diplomacy, peace, or war. The necessity for the political party's intervention appears as a consequence of the fact that the political party is a serious candidate to perform a general function in the direction or leadership of the political system and, through it, of the social system. It is in this intervention that we can find the meaning of the electoral process and the value of its results. 
In this general and multidimensional role, there is a clear distinction between the concept of the political party integrated into the political system and the concept of enterprise as part of the economic system. other than the amplitude of its spatial action, the enterprise does not appear as a candidate for the command of the whole economic system, nor does there exist any social disposition to attribute sufficient legitimacy to the exercise of that function. On the other hand, it is evident that an election has only one significance. In being recognized as or presumed to be a candidate to assume political power, the political party is expected to show its capacity to control and lead the political system. For that same reason, the political party assumes the obligation of being capable of handling the complexity and multidimensionality of the problems inherent in the political system. Where does this presumed capacity and this guarantee come from, these attributes which are expected to persist even beyond the electoral process?

The organization of the political party is a problem of importance. The political party, through its organization, has to assure positively its capacity for acting within a multidimensional context, to respond to all problems that may appear, and to take all responsibilities for decision- 
making. This is not an easy task, as proven by the magnitude of the problems to be faced.

It may appear to some that it is unreasonable to convert the "social dignity" of the political exercise of power into mere problems of organization. It may not seem acceptable that the political and social status of the political party may be considered dependent on the quality of its organization.

More important than the organizational efficacy of the political party, which remains a value of technical sort, would be the guarantee of its moral and political status, which identifies the personalities forming the political party hierarchy. In any case, it would be legitimate to have a strong preoccupation with the organization of a political party when it is certain that an electoral victory will allow for the party hierarchy to occupy the organizational structures in the state apparatus; through the use of these services, the political party will exercise the general function of governing the political system.

Accepting the organization of the political party as a problem of lesser importance implies acceptance of the idea that the political party will not succeed in reaching its first objective: the capacity to resolve problems within the political system. In this context the underplaying of 
problems of organization would imply accepting a specific form of electoral fraud and unfair competition, by admitting that there will be political parties running in the election without the proper conditions for executing the power delegated to them. It cannot be assumed that the voters, in making this delegation, have full knowledge of the deficiencies. It is obvious that, if there is such fraudulent behavior, it can be denounced and corrected in future elections. However, the rhythm of decisions and the irreversibility of many of them proves this process insufficient. The political parties ought to be able to perform the general functions which they are candidates to perform.

The devaluation of the importance of any form of organization in the political party has as its result acceptance of the idea that the state is a group of organizations absorbable through the electoral victory. When the state had a very limited area of social action, either in responsibility or in extent, this alternative method of organization could have been sufficient and efficacious. In the libexal tradition, there would be more importance placed in the capacity of people in politics to determine points of understanding between active social forces, in such a way as to define the lines of national 
politics that correspond to the maximum possible consensus and social dynamism. This tradition has been surpassed by the enlargement of state functions and, nowadays, has a specific intervention in becoming a source of political issues. In today's world, it is nonsensical to consider the state as a group of neutral organizations that might be captured by the imposition of electoral results. Nor do the contemporary functions of the state allow it to be considered as a simple factor in the resolution of social conflicts, for the reason that it is also an integrating and active party in that same system of conflicts. In prolonging the model of frictionless instantaneous occupation and in attempting to turn it into the perfect successor to a nonexistent or flawed party organization, there would be surprises or illusions for the civil servants who find themselves removed for political reasons to give place to new civil servants as a result of elections. The new civil servants and new leaders alike would then become obliged to recognize that knowledge cannot be improvised, and neither can the human means necessary for the preparation and execution of political decisions. The political party must recognize that the replacement of some civil servants will not be sufficient to give it control over those organizations. The exercise of power, in 
general, requires understanding the instrumental importance of the state as a political instrumentality, having a precise notion of how to operate within it, and how to direct it.

As happens with computers, mere instruments of calculus or processors of great power and capacity, the quality of the final product depends on the quality of its programming. The state, understood as a complex of organizations, is not much different. The quality of its programs in directing its functions accounts for the improvement or degradation of the political problems that can originate, regardless of the degree of control that the political party might have over these organizations. The problems of organization are not solved by the traditional model of replacing individuals who hold key positions. By not being prepared for the conquest of the occupation of state apparatus the winner of a political election diminishes its own political power, instead of enhancing it. The illusions of the electorate might ultimately become the illusion of power. The Variable in the Formula of Distribution of Political Power

The political party is an organization within an arena of political competition. It is part of a competition which 
takes place at several levels and is a direct or reflexive manifestation in each of its areas of activity.

Whenever the political party pays less attention to its function of representation, it is only natural that this lack of interest puts at risk its relations with the social groups that it represents and invites other political parties in this same area to intervene. If its capacity of rationalizing the social interests that it represents is unsatisfactory, it is most likely that the political party will stop receiving support from those social groups or, for that matter, having relevance in providing that service. This competition becomes more acute during the period of elections.

The verification of a certain electoral result should not be regarded as the unique basis for an analysis of the political party. In obtaining a specific electoral result, it is implicit that many other functions were activated, and analysis of them would be more important for the interpretation of the political party's actions; there remains the explanation for an electoral result that cannot be understood per se, and that will permit comprehension of the options taken previously or in determining the future efficacy of the exercise of the power that such an electoral result legitimizes. Notwithstanding what was presented, it 
is also true that the electoral result constitutes in itself an essential measure, a yardstick for judging the political party's activity.

One of the organizational specifications of the political party is in its being an entity prepared for political competition and having well-defined electoral goals, that is, expectations of its particular collective behavior. Here is found a clear distinction between the political party and any other organization that might interfere in the political system. In case of an electoral victory, these other organizations will assume the theoretical status of a political party, although they may have adopted other designations or other models of organization. The political party is, therefore, an organization that is associated with a certain measure of political power socially legitimized. Nevertheless, a singular political party does not possess all political power, even though it may hold the larger portion of the electorate, for there are other ways to control political power outside the status of electoral legitimation. The political party as an entity with political legitimacy becomes the necessary intermediary for political action, including for other organizations with political power but which lack electoral legitimacy. In other words, the 
political party can accumulate political power that can be found socially active, although electorally unrectified. Consequently, we can consider the political party as one of the variables in the formula of distribution of political power.

In most democratic societies, the general function of power distribution is performed by elections, according to the conditions of definition engraved in the legislative articles of their Constitutions. It would not be difficult to enhance the field of possibilities to include other political regimes that do not use the distribution of power in accordance with the electoral formula: the bureaucratic groups, social coalitions, or corporate entities can be perceived as "party forms" or "party contexts", when they happen to be organizations where political representation and political expression take place. ${ }^{5}$ The main difference between these two forms of distribution of power is that, in the latter case, it would be more difficult to look for an objective measure that can justify the distribution of power. For identical reasons, the distinction is unclear between the "party form" types, and social organizations with a sense of their mission to participate in the

${ }^{5}$ Joaquim Manuel Garcia Lopes, "Contextualização Politica," in Portugal e os Politicos, (Porto: Nova Barca, 1978), p. 83. Author's translation. 
political system, without necessarily being "party form" types. ${ }^{6}$ Also, the specificity of political action becomes less clear, as its relative autonomy is at stake, by the possible interference of other entities subjected to other rules of functioning and competition.

In a democratic regime, what is necessary to underline is that the electoral measurement of legitimation of political power is not a definitive measure of effective power: only by coincidence would the two be equal. The legitimized political party is perceived by other unlegitimated powers as a center of attraction, and they expect to use this socially acceptable channel to reach their specific objectives. Therefore the political party should not be described as a structure that enjoys stability and is circumferencially definable, but rather viewed in perpetual evolution, resulting in a network of relations of attraction and repulsion established with other entities. The Center of Political Decision

More than any other function, this one is uniquely visible insofar as identifying itself as a specific center of political power is concerned. It gives an objective to the political organization, and, directly or indirectly, it is also a function of that same objective by gathering many

${ }^{6}$ Ibid. 
of the necessary means for its existence. This is basically the foundation of the function of representation and what gives credibility to the function of rationalization of social interests through its specific political expression.

It is not surprising to find here an essential characteristic of the political party: recognition as an organization with a vocation for the conquest and the exercise of power. The political party is a competitor for the social concession of power. When not assuming all consequences deriving from this position, the political party may lose its relevance and only with great difficulty will it be able to assume the possibility of intervention in the political system. The social relevance of the political party depends on the quota of power that it conquers, preserves, or is associated with, all functions of the political party being oriented to this end.

For the existence and continuity of the political party, it is not essential that it should occupy a dominant position in the formula of distribution of political power. Being a center of political power does not mean that the political party is seeking to become the exclusive center of political power. Less essential would be even the necessity of total control over the organs of sovereignty that effect permanent regulation of the political system. These are 
important limitations that qualify the generic concept of the political party as a center of power, and clarify more precisely that it is a center of power which has to be compatible with the existence of other centers of power. Whenever the political party represents groups and social interests whose function has not been transferred to any other entity, the political party still preserves the status of a contender in the distribution of political power. If not attributed a dominant position, the political party will continue to be an intervening element in the general process of decision-making. If the function of social representation had not been transferred, it would go on existing with social interests and groups that depend on the political party to express their goals in the political system. To forget or relegate to a secondary position the function of political expression would create a dynamic of alienation of those social interests and groups in relation to the normal functioning of the political system.

In theory, this dynamism of alienation should generate the justification and the opportunity for the appearance of a new political party expected to take over the function of political expression. Since the process of readjustment is not instantaneous, the practical consequence of existing political alienation is the submerging of the path of 
violence that could jeopardize the normal evolution of political life.

Abandoning and distorting the function of political representation can lead to instability in the political system, making difficult the exercise of any sort of political power, either "dominant or subsidiary." direct exercise of power, however, is not an essential condition for the existence of a political party. Instead, it is crucial to prove its capacity to exercise power.

These two lines of analysis converge in the verification that the political party will hold a significant amount of power if it is effecting its function of representation of social interests and groups, although not always is it expected to hold a position of supremacy in the distribution of political power.

This political reality may appear somewhat incompatible with the proposal to restrict the common notion that the final goal of the political party is the conquest and exercise of power. Nevertheless, the political parties have their inevitable role in the political system, and, in particular, in pluralistic democratic regimes. It can be

\footnotetext{
${ }^{7}$ Pedro Santana Lopes and José Durão Barroso, "Excertos de uma Entrevista Concedida ao Jornal Tempo, por Pedro Santana Lopes, em 14-08-80," in Sistema de Governo e Sistema Partidário, 1st ed., (Lisbon: Livraria Bertrand, 1980), p. 107. Author's translation.
} 
admitted that it is in these manifestations of the political reality that one of the reasons for instability in the political system resides. The pressing necessity of gaining power can cause the political party to transgress basic political values established in its formation, which ought to be interpreted as a possible solution to deficiencies of its constitution, therefore facing problems that were not properly equated and resolved. There is not an initial solution for a derived necessity. There is a diversity of examples of structural or organic deficiencies that generate distortions in the relations between the political party and political power, making the party dependent on the exercise of political power. The most frequent defects are insufficiencies in the organization, resulting in political attempts to compensate by the takeover of state organisms, resulting in situations of paradox, in which political programs are devised only after the conquest of power. Debilities in the function of political representation result in the political party's attempts to overcome them with promises of services to be provided after the conquest of power, and which in their expression tend to be maximized in order to attract the support of hesitant voters. There is the necessity to resolve internal problems of organization through the relocation of elements that are a 
factor in internal conflict. This is a practical extension of the use of the state to compensate for deficiencies of internal organization. Generically, all these procedures and last-resort types of solutions are based on the traditional concept that political power is a scarce social good to be conquered and accumulated. It is absurd to conceive it as a collective good to be socially shared. Those who have the power use it, and, because that is useful to the political party, it is necessary for it to gain that right of use.

Under these terms, the conquest of power is not understood as a way to exercise a political conception, but as a device to ensure the continuity of the political party, irrespective of all its deficiencies. This situation of cover-up can be driven to the extreme, in which the conquest of power becomes the objective to be superimposed over all other ends. Dissatisfaction in the situation of crisis is at any cost replaced by the chimeric idea of the conquest of power, the only condition for subsistence of the political party, or at least of its hierarchy. Once power is conquered, all is justifiable. It is a high-risk game, characterized by a dangerous instability for the political party and for the political system in question. 
When political power is conquered, the price of achievement is a diminished control of the exercise of that power. Too much has been promised to too many different interests for fulfilling the contract. When the political party fails to conquer political power, the reconversion of its position is only possible after profound, and slow, transformations, leaving this political party temporarily neutralized, without much capacity for exercise of its normal functions.

The escalation of competition among political parties can take them into a state of collective hysteria, in which all political parties will make their best effort to take advantage of the benefits of the defeat of other political parties. The results of this situation are the insecurity of power, the increase of instability in the political system, with the ensuing incapacity of some political parties to perform their functions. In this case, it is important to analyze what leads to this situation of collective hysteria, and to consider to what extent this high risk is socially justifiable. If analyzing a commercial enterprise, it would be easy to conclude that no stockholder would accept of his own will the financing of any such type of decision. Apparently, because the continuity of such an enterprise has more importance in the 
eyes of Western society, the deduction might be that the margin of risk taken by the political party is not acceptable in the entrepreneurial world. Nevertheless, the social function of the political party is more important than the social function of an enterprise, and its instability or functional disrupture will have effects of more serious significance than those of the bankruptcy of an enterprise.

It may be concluded as a political reality that the effects of the emotional pressure associated with the relations of political power that have been described are stronger than the principles that should legitimize them. The Function of Political Domination

For some theorists of political science, the political system is considered a subgroup of the social system, where it manifests itself, is allowed to diffuse itself, and regulates the relations of power and of authority. It will be necessary for an organization that intends to act in the political system to establish a relationship with power and authority, that is, to come up with a conception of how to exercise the power and authority. Reference to the political party requires specifying the content of this function. In this context, the natural relation is to be designated as a relation of political domination. In this 
relationship, power is to be understood as a way of action that permits the conditioning or determining of the action of others. On its most basic level, the act of domination is the result of an imposition, a direct exercise of power. However, it is not always essentially in this pattern. There are ways of dominating that are perhaps even more efficient than the direct act of imposition. Political action is an integrating part of a competitive relationship among the political parties, leading to a particular distribution of political power. The function of political domination shows itself in reference to the use of that amount of power that is attributed to the political party. This superficial and traditional image does not show the complexity of factors present in the practice of the function of domination. This is not a linear relation of cause and effect or, at least one that only has that form in cases without any great political concern. The function of domination is not exercised by anyone who may so wish, even if the person in question holds some substantial power. Consider, for instance, that to win a political election means to have a dominant position in the formula of legitimate distribution of power, but it does not imply, per se, that this power can be effectively exercised, and, much less, that it will be translated into authority: that is, 
into a power that is formally legitimate, politically respected, and socially accepted.

The exercise of the function of domination cannot be limited to specific cases. Otherwise it is a sand castle type of power, and its specific decisions will be absorbed by the flux of events and subordinated to a general dynamic that it cannot resist. It is necessary that the overall actions, resulting from all the specific decisions, have a consistent pattern of harmony before they become mutually articulate and strengthen the acts of domination. Therefore, the exercise of the function of domination is more a problem of the quality of plans of action and of the social recognition drawn from that harmony than it is a strict matter of force or of an affirmation of power. In order that the exercise of power be consistent and that the relation of domination does not become onerous in terms of needed resources, it is necessary that the specific content of power used be socially acceptable. Only in this way can the effects of amplification and social reinforcement of the political decision be achieved.

Usually, it is not this spontaneous image that is associated with the exercise of power, and, for that matter, it is not the natural image to be attributed to the formation and the exercise of political power. The relation 
of power is frequently tested and recognized in an individual perspective: it is a specific relation to be defined when facing a specific problem which exerts a coercive imposition. Someone uses power, and someone or something suffers from it. It is a precise situation, where, only with some effort and analytical distance, can we find a logic of harmony, and the compatible articulation of multiple decisions. Political power is regarded as the necessary capacity to reach an objective. Those who hold power use it. Those who hold power have the capacity to attain their chosen objectives.

This spontaneity of the notion of power, originated by the individual experience, and, later on, confirmed by the observation of collective behavior, or in the reaction of the social masses, has considerable political impact. It forms the basis of the credibility of all political promises and, in general, of any electoral propaganda. It is because of recognizing that power exists, as a way of making selected objectives become realized, that belief in the political party can achieve the chosen goals, provided that all necessary power is delegated to it. It is, at the same time, obvious that this spontaneity is also the basis of all political disenchantment: when promised goals do not come true after political parties have been delegated power, and 
have exercised it. Nevertheless, the notion of power does not cease its existence but rather, proves itself as having been unduly credited. Perhaps such a situation might alter the voting option of the electorate in the next elections. The notion of spontaneous power is an illusion in facing the reality of politics. The political power exercised in the political system has effects throughout the whole social system and, with it, the activity of directing the social system is perpetuated. There are no particular decisions for objectives separately defined and chosen. Instead, there is a general harmony of decision and patterns of transformation composed by multiple objectives, either simultaneous or sequential. It is the articulation among these multiple objectives that makes possible the effectiveness of each one. The general harmony of decisions permits the conditioning or the determining of the decisions of others. Without this, the function of domination in politics would be seen as a mere variation of police surveillance, as a direct exercise, permanent and singularized, of political imposition or restriction of liberty of each person living in the society.

In a democratic society, free in its political expression and pluralistic in its social representation, it is not the fact of a decision being supported by the 
established power that will confer on it the necessary conditions for success. More important seems to be the social recognition of the quality of the proposals in relation to those of any other contender. The function of political domination loses part of its imposed power and coercive effect, and in its place comes to be seen the quality and the harmony in the exercise of power. The power of imposition and coercion is becoming less and less significant in the contemporary world of political action. The possibility of the establishment of a restricted amount of numerical relations or even individualized relations, between the power holders, the representatives of social interests, and the citizens, becomes an impossibility after the sudden growth of the electoral universe, and its enlargement to a greater number of other social areas, where there is a direct or indirect interference in political decision-making. The individualized relation or its eventual possibility, in which the traditional exercise of the power of imposition or coercion was structured, is now transformed by the crucial importance of the dynamics of social groups and collective movements. This alteration constitutes one of the manifestations of the political question specific to our time. The increasing importance of group positions and the expression 
of collective movements demands that the political power, among other things, be exercised much more in terms of acceptance than in terms of imposition. The act of imposition will be transformed into the act of manipulation, with the objective of stimulating or justifying the acceptance of the decisions taken. In this transformation lies some of the importance given to social communication in forming and diffusing political decisions. With the decline in the efficiency of the means of individual coercion, that now have a real effect only in problems of marginal importance in which an individualized relation is still predominant, it is necessary for power-holders to detect in advance what can be done within the conditions of social acceptance. Only after this perceptual work is done does it make sense to propose the rationalization of this path in an environment that ensures sufficient social cooperation. To political decision-makers, more important than the right of imposition is the capacity of interpreting what guarantees the social acceptance of their decisions. Otherwise, it is only justifiable at a heavy investment of political resources, if the goal in question has an elevated political and social value.

Contrary to what we might think, all this does not imply that the function of domination has become irrelevant 
or nonexistent. On the contrary, it means that the function of political domination is in a perpetual process of transformation.

The process of domination has translated itself into a sequence of general restrictions. That, through a series of periodical and momentary balances, allows the formation of collective movements compatible with the orientation of the political decision. It evolved from the necessity to condition crucial personalities and small groups to the necessity of conditioning larger groups and social masses. The political party phenomenon itself, recent in the history of politics, has emerged from this basic transformation.

Political party pluralism corresponds to the necessity of bringing into the political system the existence of social groups with a capacity to interfere in the process of political decisions. It would be difficult to understand that political reality, being inherent in the transformation of the conditions of political action, and, in particular, in the value of imposition, would not cause the political party to change its traditional conception of domination. It is the actual existence and the running of the political party itself that confirms this shift in the traditional notion of power as coercive domination. 
It is natural that this kind of evolution requires a far more complex organization of the political party. A linear function of domination expressed by imposition permits the personalization of power, because this is only possible in an individualized relation. To understand that this simplicity does not exist or is not even possible today implies recognition that the personalization of the command of the political party organization is an inefficient solution to the political problems it faced.

In this new line of observation, we can verify that the specific characteristics of political party identity are not independent of the types of problems to be resolved and of the specificity of the political system in question. Assuming that its relevance begins with the appearance of mass social movements, the political party still keeps traces of previous periods, namely the personalization of its leadership. As political party actions cover more areas of human life, they have also gained complexity, losing the personal touch of the exercise of power, to receive progressively the collective mark of an organization. Today, a political decision is incomprehensible if isolated, but comprehensible if seen as a sequence of multiple decisions; the personal touch can exist only when accepted by complex and diversified organizations that 
assure the necessary conditions for its execution. Even in cases of strong personalized exercise of political power (such as in American presidentialism), this is visibly the result of the organizational work of the political party and governmental institutions, without which no satisfactory consistency in decisions would be taken by a simple political actor. The Function of Political orientation

The function of orientation is the affirmation of programs, policies, and resolutions of political problems. Its practical formula is in the model of orientation suggested by the political party for the social system. In an exaggerated way, some theorists designated it as a societal model, although its existence precedes the existence of all political functions, and, therefore, the political party's functions are instead related to the existence of society as those of an entity with independence and singularity. starting with these basic ideas, several political situations emerge.

When associating with the model of orientation of the political party exercise of the function of domination superior to all its competitors in its quality we may find that all necessary conditions are gathered for the effective exercise of political authority. There is legitimacy that 
derives from the electoral results, the capacity to dominate, which allows the political party to overcome or neutralize resistance. The general sense of orientation brings a necessary harmony, and gives consistency and efficacy to the sequence of political decisions. There remains a well-defined relation of democratic authority along with the exercise of power, party activity, and society, as shown by the social credibility of political decisions.

If the political party does not have an electoral majority, the exercise of the function of domination is at stake. Depending on which type of model of orientation this situation may produce, and of the degree of compatibility with other models of orientation of the other political parties, there are two possible solutions: the political party can become a member of the opposition or establish an alliance with other political parties in order to participate more effectively. It is also viable that a political party may exercise a specific, and effective, function of domination, without having either an electoral majority or without a model of orientation compatible with that presented by other political parties. This is a specific modality of opposition which can be designated as counter power. In any case, all political parties exercise 
a certain function of orientation, just as they all exercise a certain function of domination, irrespective of whether or not they occupy any positions at the executive level of the political system.

Historically, the changes verified in the function of domination, show, as a direct consequence, the growing importance of the function of political orientation. In immediate terms, this is the natural result of the necessity that political power has of explaining and justifying itself, in order to be accepted and have its prescriptions observed. To be more precise, this is the result of the political power being confronted with social mass movements uncontrollable by traditional coercive means.

The stability of the political system and its capacity of administration of the social system are dependent not only on the quality of the political programs and the harmony of decisions, but, above all, on the success of its social diffusion. The function of orientation has the objective of systematic control, meaning the efficacious and balanced articulation of all the elements of the social system and all dynamics present. To attain this objective, it is necessary to create a social environment receptive to these political measures. Therefore, the function of orientation is not limited to the activity of pure political 
conception. It is a very specific type of activity that compensates for the reduction in the efficacy of the traditional means of domination.

In perceiving the function of orientation as a measure of the compensation believed necessary by the changes verified in the function of domination, it is understood that its importance is not only in the exercise of the executive power, but, as well, in the exercise of the right of opposition. In a political system conditioned by the function of antagonistic orientation, there are problems in the performance of the executive power, even though its function of domination is strongly associated with majoritarian support. In this circumstance, the relative political power of the opposition is superior to what the electoral values allowed for in political situations in the past. On the contrary, a broad consensus in the exercise of the function of domination permits to an electorally weak political power implementation of its program without any major problems. This sort of analysis allows conceiving situations in which an electorally strong political power finds itself with the impossibility of exercising its own power. It is only necessary for the political power to find itself incapable of producing the function of orientation, from then onwards for it to be limited to the practice of 
erratic decisions, without a comprehensible social set of purposes.

This aspect is not only the result of a numerical and qualitative change verified in the composition of the electorate. It is also the result of contemporary societies presenting a strong dynamic of evolution and mutation, which makes future horizons into an essential element of the political decision. In this perspective, the function of orientation appears as the production of goals that give finality to present decisions, integrating them into a consistent path. The harmony of decisions, previously referred to in the exercise of domination, finds here its strongest justification. Today, this harmony has to accept the expectations of the speedy evolution that characterizes the present social system. It is not sufficient that the function of the exercise of authority may assure the service of a balanced distribution, which would be satisfactory in a situation of social stability and a slow rhythm of transformation. Instead, it is necessary that the general political function deliberately provoke imbalances in the distribution, as a factor of progress. It is expected that, in such cases, the risk of political action is superior to that in situations of stability. In order to control this excessive risk, it is important that the output of the 
function of orientation offer consistency in the succession of decisions and that its purposes be socially recognized.

It is evident that there are important consequences resulting from the political party actions. The political party, with an organization essentially directed at the conquest of power, and aware that this is the universal means for access to authority, develops then to the level of demonstrating that authority can only manifest itself socially, when there is a harmony between the power holders and the interpretation of their decision, which takes place in society.

Where before, there was found only a group of personalities with a vague amount of programmatic positions, now it is expected that there be found a multidimensional organization with a capacity to interpret, integrate, and transform all social phenomena. Otherwise, there will be no exercise of power, for that path brings only more illusions. The Network of Internal Conflicts

The political party is dependent on its human composition, which gives practical content to its organizational structure, conditioning or determining the political party's behavior, and, to some extent the interpretation of the political necessities and opportunities. No matter how rigorous the formal conception 
of the organization is, actually it will always be the people who will leave their existential mark as a political reality.

Under this perspective of the exercise of hierarchical powers the distribution of seats, positions, and functions among people the organizational dimension of the political party will reveal itself as one of conflict. In one way or another, all organizations have conflicts to be regulated by their structures. In a political organization with its action confronted by either express or latent conflictual tension, this is a more constant characteristic. There is a conflict that must be strictly considered to be of a political nature. This is the result of the tension generated by the political decision itself, which requires choice between objectives in incompatible, complex situations. Political decisions concern the regulating of social behavior, with specific rationalities, and involve having to choose among different levels of satisfaction for different interests represented by the political party. And, once in power, harmony ought to exist between the objectives previously defined and the necessities imposed upon the political system. still, in political party organization, there is also another type of conflict, much more important for the interpretations of the political 
party's decisions pertaining to specific situations. It is a conflict that results from inevitable relations among personalities, relations of solidarity and alliance, of complicity and converging interests.

Whenever the organization of the political party is thought of as not of a secondary nature, it is also understood better as being a dynamism of conflict, with repercussions at several levels. There is a relation of conflict in the formation of the political decision, a product of that organization. Conversely, there are relations of conflict between groups, factions, and social bases that are represented, searching to obtain relative advantages and as many possible rights of expression of their specific objectives. Finally, there is a relation of conflict in the different ways that singular personalities and the party equate the problem of the assignment of particular tasks, and of priority of objectives, either of an immediate nature which are very important to some party members and organized internal groups, or those of a longterm nature (which are more important to the continuity of the political party).

In its own existence, a political party is not an internal unit from the organizational point of view. Under the sociological aspect or the process of formation of 
political decisions, it is a coalition of diversified interests subordinated to a complex negotiation process, although generally holding the same common political opinions. On the consistency of this negotiation and its capacity to generate stable solutions to internal conflicts depends the functional stability and programmatic security of the party's hierarchy. In fact, the political leadership needs affirmation. This affirmation can be given by force of decision and of anticipation, or by uncompromised arbitrage with any of the internal groups. Nevertheless, its actions are limited by the results of constant negotiation taking place within the party.

As happens with all complex organizations, the hierarchical decisions need to find conditions for acceptance in order to be formulated successfully. The tension created within the political party can be so decisive as to reach the point of turning the organizational question into an autonomous problem which impairs the political expression of the political party. This would be the same as to recognize that the political party has become independent of the form and functionality of its organization.

If we are to regard the political party as a stable coalition of interests, then it will not produce an 
oligarchic organization but a participative kind of leadership, receptive to suggestions coming from organizational channels and through which any needed replacements can be effected without creating a crisis. If, on the other hand, we are to understand the political party as an organization perpetually at risk of internal conflicts or as an organization that might take political stands contradictory to the immediate interests of its social bases, the organizational problem would then probably be thought of as an autonomous subject, and able to concentrate on the solution of the problematic relationship between the hierarchy and the party organization, and on the logic, and the justification of its political action. This is the perverse effect that may happen when the political organization has as its main objective the continuity of its hierarchy.

This new analytical perspective offers one more contribution to the idea of the relativity of the political power. The exercise of power here reappears at a more elementary level embedded in the internal life of the political party. In a certain way, the problems that the leadership of the political party find in relating to the membership, are as restrictive in their manifestations, as are most problems of articulation with the political system. 
Both the process of formation and of execution of decisions, and the exercise of authority inside the political party, are not linear procedures. They are transformed and distorted by the types of forces that exist, by divergent and convergent interests, and by the specific capacity of the organization. The decision as to how a process of authority is to be interpreted as a signal undergoes several "filterings" and "reflections," merely to read its hierarchical position in order to determine with rigor its final meaning. ${ }^{8}$ The Difference of status as the Political Identity

It is clear that the political party has its own identity. It is an identity that manifests itself not only politically and socially, but also in other areas, such as in the organizational structure or in the relations among personalities. In normal conditions, the political party should have a correspondence between its political identity as shown in its political function of expression and its social identity as being the support and origin of its political function of representation, and the reasons for delegating power.

\footnotetext{
${ }^{8}$ Hermano da Silva Azevedo, "Estudos Politicos," [first draft], 1987, Lisbon. Author's translation.
} 
It is not by a name and a symbol that the political party is designated and in which we can find its identity, although they are details of crucial importance during an electoral period, when the voter in a multi-party system may have problems in recognizing names and symbols. Instead, the relevance of the identity of the political party is associated with the political services rendered which constitutes its social justification for existing as a means of representation, a center of rationalized political expression, and as a competitor for the distribution of power.

As happens to other entities, the political party's identity has a differentiating effect when compared with other political parties. The political party's identity conditions the effects of admissible fluctuations in the political party's position and expression as a reaction to political opportunities offered by the current evolution of events. Its identify contains a genetic code, where the conjugation of its origins, its historical options, its specific ways of representation, and its expression of social concerns may be found. It is this genetic code that determines the very space that the political party occupies in the political system. 
Breaking away from the political party's genetic code may appear sometimes to be a useful short-run strategy, but usually it implies the loss of differentiation in relation to other political parties, and at stake are the conditions of the existence of the party itself. Once more, it appears that the freedom of decision is not absolute, and anything stopping short of respecting such restrictions may be a mere illusion of freedom, since it can lead to the annihilation of the social and political importance of the political party. The differentiation of the political party cannot be described as absolute or rigid, just as it is impossible to use similar adjectives to differentiate among social groups, organizations, and individuals seeking a certain political party as a channel of representation and expression. It has already been verified that the political party is not an isolated entity and that it is by no means of a selfsufficient nature. It is dependent on its connection with social groups, organizations, and people. Without any of the above, it will be unable to attain a lasting relevance in the political system, although it may be capable of having some conjunctural importance. For this same reason, the existing variations in the political party's position are to ensure an adjustment to the corresponding variations of the position of social groups to which it is related. 
The disruption of this balance means the degradation of conditions affecting the action of the political party. Thus, the interpretation of its identity is made up of natural objectives established in the internal conflict for the formation of political decisions, and, especially, for strategic decisions. The principal pretext for this internal conflict is the definition of the party's position in relation to the diversity of interests that it represents, and to its reaction to the problems and opportunities that are present at each moment. In zddition to being a constant pretext for an internal conflict and a consequence of the fight for dominant positions in the interior of the coalition of interests that forms the party, the identity of the political party is the primary condition for the definition of its electoral position. The effect of being able to specify an identity in its delimitations and in differentiation is, in itself, an aspect of major importance. It determines the conditions of preservation of the political party's natural basis, continuing its perception by the public as the party to which to delegate representation and political expression. Furthermore, it also gives an opportunity to capture new votes, in return for its services of representation of diffuse, unhappy, or 
merely intermediate social groups without any stable political representation.

These are two effects that, in general, have contradictory results. The first reinforces the political party's original identity, but also keeps it limited to its normal size. The second diffuses the perception of the party's identity and enhances its agglomerating capacity. It is a complex relation, over which crucial strategic decisions need to be made. 
CHAPTER II

EXOGENOUS FACTORS

All the endogenous factors so far deduced about the political party are already sufficient to establish some current definitions of what a political party is. Joseph schumpeter defined a political party as "a group in which its members decide to act conjunctively in the competition for political power." Giovanni Sartoxi: on the other hand, saw it as "any political group that presents itself to elections and has the capacity, through the elections, to place candidates in public function."10 Nothing here explains any of the endogenous factors previously analyzed. Those factors, as well as the generic definitions of the notion of a political party, are flawed in their conception by observing the political party as an isolated entity. The action of each political party is not independent of the action of other political parties, and, in general terms, of the action of all political agents or social entities with some political relevance. The interrelations among political parties are a permanent characteristic of

\footnotetext{
${ }^{9}$ Joseph Schumpeter, Capitalism, Socialism and Democracy, (New York: Harper and Brothers, 1942), p. 283.

${ }^{10}$ Giovanni Sartori, Parties and Party Systems, (London: Cambridge University Press, 1976), p. 64.
} 
political behavior. The effects of these relations are not only evident in the reactions of the party to other political parties' actions. It is the notion of political possibilities itself that is influenced by the global framework of decisions and of actions identifying each and every politjcal moment. It is also not difficult to verify that the freedom of decision of the political leader is restricted by a variety of factors: the internal structure of the political party, the actions taken by other party leaders (to whom the leader ought to reply), the new possibilities that may derive from these actions (these must be taken into account in reaching a decision and may imply the need to follow a path which is not in the decisionmaker's personal interest or normal to that political party's action). The political arena is replete with a multiplicity of elements, and the position of each element in the political spectrum is relative to the others. This is a dynamic sort of relation. Thus, any references to the position or movement of a political party cannot be examined without taking into consideration the internal elements and, obviously, their specific value and possibilities can be found only when considering the external elements. 
The Network of Relations Among Political Parties

The political party, an active entity in the political system, is the function of a relation established with other political parties, organizations, and entities entrusted with political power. Here it is necessary to shift from the perspective of the existence of the political party to that of the relations among political parties. The latter perspective only makes sense when preceded by the existence of the political party, and the existence of the political party would still make no sense without the political relations among parties.

To some extent, the analysis of the political party is the study of how it articulates its existence in the political relation. The appreciation of one of these elements is not independent of the appreciation of the other. This new perspective of the relation among political parties transforms all other factors already present into mere relative expressions, that is, forms and values, where nothing is definite or absolute.

other factors have to be added in order that the results obtained can be used with sufficient certainty. It does not matter that the image which the political party produces of itself, in relation with other social groups, purports only to represent and express itself politically. 
Politically it is also of importance that the image produced by its relations with other political parties and the organs of sovereignty not only determine its positioning in the scheme of distribution of power, but also in the justification of its behavior before its social bases. No less important is the approach that the political party takes to problems and opportunities generated by the evolution of the political system. All takes place in a space of competition, where there are other political parties willing to exploit any mistakes and use advantages that may come up.

In general, this sudden enhancement of perspective coming from the inside out, from the existence to the relations, proves how the political power, usually considered as an absolute objective of political party action, is not, after all, an attribute that can be understood as a specific value that the political party should hold. Political power is a relation that takes place among multiple entities and agents with political relevance. If we were to perceive political power as an objective reality, it would be fluid, mutable, and in many ways, conventional and indeterminate in time. In conquering power, the political party continues to be only a part of the system of relations in which power is produced, 
accepted, and recognized in its effects. It is not the political party which is in power.

Power defines itself in the system of relations that allows its practice. The balance and stability of the system of relations depends on the social reality of that same power.

This is not an exclusive characteristic of the democratic and pluralistic regime. In authoritarian and totalitarian situations, political power continues to be relative: there are too many concessions that the dictator has to allow in order to maintain a special form of balance in relations that will permit him to exercise authority.

If the exercise of domination imposes the harmony of decisions, our perceptions of the political relation indicate that the exercise of power, apparently the total affirmation of the liberty of decision, is not simply an isolated act, but represents the harmonization of a specific system of relations.

The Network of Relations with the organs of Sovereignty

The network of relations of the political party does not restrict itself to interaction with other political parties, although this is its central area of competition, which it is always necessary to consider more carefully. 
Despite the constitutional system that regulates the relations of power, and regardless of the relative importance that the political parties may have in the formation of political decisions, the primary request for its analysis is the scrutinizing of the way in which the political parties articulate the diversity of positions that they assume throughout their existence. Each political party has to consider the effects of its relations with other centers of power. These centers of power are not necessarily direct rivals of the political parties, but are found present in the same political system. In one way or another, these centers of power condition the political party's position and the possibility of moves it can undertake.

The position of each political party is not independent of the options taken towards other kinds of relations in which to engage in these other centers of power and the place that these relations occupy in the development of its strategy. The importance of these relations will be in direct accordance with the political influence and constitutional status of these centers of power. The relations established with the organs of sovereignty are to be understood as being of differing importance, according to the constitutional dispositions 
adopted to rule the daily life of each political system. A multiplicity of forms of relations is, therefore, possible, from pure parliamentarianism, where the organs of sovereignty are the result of the political parties' relations, to that where competition among political parties is emphasized, to pure presidentialism, where the autonomy of the political parties and their capacity to control the formation of the political decision is underplayed in favor of personalized power, which positions itself above these restrictions. Nevertheless, these formal structures do not rigorously determine the types of relations to be established in precise situations of contact between the political parties and the organs of sovereignty. The constitutional dispositions only delimit a space of normal possibilities for the political system. Actually, it will be the real activity of the political party that will finally define the configuration of the system of powers. The same constitutional mechanism can have different practical results that are dependent on the way of action and the capacities socially recognized belonging to the political parties and their political agents. From here, this area of political relations is to be perceived as strategically open, though delimited by formal rules that 
have to be respected and, above all, politically interpreted.

Even in the case of pure parliamentarism, the analysis of the relations with the organs of sovereignty is not a mere variation of relations established with the political party. A political party in power or one that is being represented in an organ of sovereignty is a different political party, and not always is this difference a result of being connected to the instruments of political command.

A political party in government is a double entity, and it can become a divided entity. It is not assured, under any circumstance, that its presence in power is sufficient reason to believe in the simultaneous viability of that double division of the political party's structure. This problem is even more perceptible in cases of a political party's coalition. Anyone can easily verify that, in the relations of the political party with the organs of sovereignty, there are specificities that may have an unpredictable impact in the analysis of political phenomena. It is almost impossible to generalize, if we were to consider the diversity of political systems. There is also the possibility that the institutional exercise of political power is not connected, or at least not directly connected, to the political party's policy positions. The 
institutional occupancy of seats of power by elements of the political party regulates itself by the specificity of its functions, generating a significant margin of autonomy and a new differentiation of action. The effects of this phenomenon are only visible when determining the new existing opportunities.

The Relativity of the Position of the Political Party

In accepting the perspective of the political relation, the endogenous factors become relative, in the sense that they are inserted in a context of competition. The political party position ceases to exist per se, regardless of how well-founded and justifiable it is.

The election results themselves, well-defined figures at a certain period of time, are now dependent on what the distribution of votes by other political parties would be. The relevance of the political party's position is dependent on the political context, which is defined by the interactions of multiple political entities. It is not politically profitable, for instance, to be right long before this rightness is socially recognized. It is only useful to be right immediately before that social recognition takes place.

Likewise, it is always success in the future that founds and justifies beyond any doubt decisions taken in the 
present. A decision that leads to a future failure is not considered the correct decision, irrespective of its being the best reason at the moment of choice. only from the perspective of the relations can we understand that even the conquest of power at any cost can sometimes be a heavy political defeat for the political party. An exercise of power that shows unacceptable deficiencies will prevent the political party from winning future elections.

All existing political parties within a political system are inevitably connected. None is independent, and none of their endogenous factors can be studied without taking into account the complexity of these exogenous factors. The analytical reference to the political party has to be global, thus requiring a broader base of information to rely on. The Relativity of Possibilities in the political system

While the analysis of the political party as an isolated entity gives us a well-defined image of its nucleus (even if under instability and internal tensions), only its bordering contour keeps itself deliberately imprecise. The consideration of interparty relations changes these analytical results. The image of the political party is not any more simplistic. It is now a group of possibilities, with a content and variable forms, according to the 
political circumstances, dependent on the positions of other political parties, and on the manifestation of political problems.

Political action, more than ever, assumes the configuration of reaction and adaptation. The act of political initiative becomes an anticipated reaction in itself. In fact, the value of the political initiative is not strictly dependent on its originality, at the cost of being misunderstood. Its value is in predicting what the configuration of the political parties' position and politics will be, so as to attempt to occupy beforehand a position which will be of more relative worth. It is not a real initiative, but a reaction in the face of a predictable future, an anticipation. Indirectly, this reference proves that the political party has no interest whatsoever in presenting a unique position or singular image. A predictable political party is vulnerable to the anticipation of others, incurring the risk of becoming irrelevant, irrespective of its political reasoning. Conversely, the political party which is unpredictable in its political relations is at risk of losing its social connections, in a way that its motions do not hold anymore the thread of representation established with different interests, social groups, and organizations. The importance 
of the structures that make possible the relation and the effect of relativity that they have on the exogenous factors of the political party do not annihilate the restrictive effects of these factors, but, rather, enhance the complexity of its evaluation.

To choose the optimum path among a diversity of possibilities and to predict which of these will become alternate critical points is the exigency of this factor in the political party action. Its identity demands a permanent reference to its origins and its peculiarities, which make up its genetic code. The need to select possible realities among diversity makes us believe that the political party dynamic is not independent of its temporal vector, orientation, and the need to proceed to readjustments for what the future allows. The Strategic Production

It is through the perspective of the political relation that the function of strategic production becomes important. It is obvious that there already exists a strategy in all previously-analyzed functions. It would be unthinkable to conceive the function of political expression without giving it any specific strategic content. The process of rationalization of multiple social interests represented by the political party would not be possible without the 
existence of objectives, and ordinate options, perceived in political terms, and with a specific timing of implantation. A strategic production in these cases is a necessary function, in order to have valid decisions. It may even be considered that all political decisions presuppose a strategy, provided they are not situations in which strictly technical criteria and goals are sufficient to justify the choice of alternatives.

The main expression of strategy only appears when relating its configurational position and moves to other positions and moves by other political parties or important entities in the same political spectrum. This is a more general form of strategy, by which all other specific strategies are conditioned. Although they have to prove themselves compatible with the general ends of the political party, these strategies do not stop being perceived as such or even as having a certain degree of autonomy. The original pattern of the strategies is in direct dependence on the general strategic situation.

The importance of this function of strategic production is so clear that it could be tempting to assume in itself all analysis concerning the political party. The results, however, would prove unsatisfactory, as we may easily deduce from the countless numbers of attempts. The main reason for 
these fiascos resides in the fact that most analytical attempts are made a posteriori (manifestations of strategy in the political party actions) to explain a process that has its interest and significance when analyzed ex ante (before being known and objectified).

For political leaders, this is the right perspective and correct identification of a dilemma, and through them we can observe the real limitations of political party action. To accept the jdea that this political function is, in itself, the operational synthesis of the political party analysis is equivalent to downplaying the importance of all other political functions and to admit that they are directly or indirectly reflected in this hypothetical synthesis. Not only can such direct reflex not be found, but it is not possible to depart from an applied strategy to deduce all its formative components, or even to assure that all its necessary components have been effectively used. It would not be possible also to establish an effective critical analysis of a strategy without evaluating each one of its components and scrutinizing the different forms in which this could be combined in its relative effects. Neither through objectivity nor through interpretation is it guaranteed that the analysis a posteriori of a political strategy can reconstruct the process which produced it. 
What could initially appear as a useful simplification of the political party analysis eventually becomes an analytical mistake, because of the deficiency of method and of inadequate limitations for analysis of the subject in question. It is common to believe that this knowledge is a valuable indicator to the political party in competing in political events. To know the strategic option of the political party implies being able to predict its behavior, its future position, and potential consequences of its strategy. This is a domain where the illusions are at least as frequent as the objective judgments concerning the ability to anticipate, take advantage of, or neutralize enemies' actions.

Strategy is a configuration of possibilities produced by a specific process. Not knowing how to reproduce the particularities of this process prevents evaluating with precision its meaning, and leads to strategic rigidity. To know the details of the production of a strategy is to know how the strategy would react to obstacles and unpredicted accidents. It is to know the way of evolution and transformation.

The fact that the strategy is a configuration of possibilities compels definition of a realistic configuration. The aspect of compatibility of the 
configuration of possibilities with all other analytical elements is independent of the producers of the strategy. In fact, the comparison between models of possibilities is crucial to determine the viability of the strategy. We reach the indication that the strategic production is not an operational synthesis of all the activities of the political party or a secure sign of its position and movement. It is only the point of departure for the evaluation of possibilities of the position and movement of the political party. The Production of Political conceptions

As with the production of strategy, it is also easy to consider that the political conception of the political party is already implicit in many of the political functions analyzed. It is the conjunction of these political functions that will allow the reconstruction of this conceptual unity concerning the meaning and finality of political action. It is impossible to imagine the political functions of expression, domination, orientation, or even of strategic production, without the political conception being subjacent to give them meaning. The identity of the political party itself would be considered as a general manifestation of its political conception. To consider only the political conception, implicit as it may be in the 
political functions, would be admitting that it is essentially produced inside the political party, manifested through its endogenous factors, and, for reasons of strategy, adjusted to the external relations of the political party. This is not the way things happen. Political action develops itself in a context of a diversity of conceptions, some produced in the interior of the political party, and others outside the political party. This political space is also a cultural space, where we can find the translation of social attitudes. The political system orientates the social system, and nothing produced here is alien to it. This means that the political conception is necessarily influenced by factors exterior to the political party.

A political conception exists, in relation to other political conceptions, inserted in a space of competition that determines relative relevance of each party (the electoral measure). The radical novelty is not recognized as a relevant political conception, because it has no possibility of entering this competitive system. On the other hand, the repetition of a conservative conception may be of relatively major importance, for the simple reason of being easily recognized in the political space in which the political manifestation takes place. The capacity of 
achievement associated with the political conception is directly related to its social credibility; "there remains its support and operational means." 11 Already mentioned is the necessity to take into account all other competing conceptions, in order to be able to locate each model of political action.

This is an analysis of the political party position in relation to other social ways of comprehending the political function in general and the political party's action in particular. For that reason, there may be questions as to the meaning and social justification of political power, in reference to other options to leadership of society, and appropriate ways to ensure social mobilization and cohesion in resolving specific problems with the available means. No political party can have its social affirmation without having answers to these types of questions. As its content changes with time, it is important that an adequate adaptation of conceptual formulas exist, in order to maintain stable answers to these questions. The challenge for change is, therefore, exterior to the political party.

\footnotetext{
${ }^{11}$ Arlindo Caldeira, o Partido de Salazar-Antecedentes, organizacao e Funcōes da União Nacional (1926-1934), (Lisbon: Analise Social, 1986), p. 74. Author's translation.
} 
The conception of the space of production of the political concept is, not only an exigency of theory, but a practical political necessity. The success of a political proposal, regardless of its quality and complexity, is not independent of its social acceptability. Political action is orientation and transformation. The political party cannot reach these objectives through destruction, imposition, or strict domination at the risk of political action becoming an absurd illusion of what is intended. Efficacious political action is closely related to the social, cultural, and ethical manifestations that characterize any society and give consistency to its social relation. To orient a society is to understand the social behaviors and patterns of that society. This idea ought to be present in the political conceptions of the political party. The enlargement of the space of competition comes from the amplification of the political action in social areas that not only include the political parties, but also the political institutions and other entities with a political vocation. All goes to emphasize the multidimensional character of the political action, and, consequently, of the political party's action. 
Financial support

All political organizations need financial means for their existence. The financial factor concerns funcicionality. Keeping in mind the importance given to the organizational aspects of the political party and the complexity of its functions will help in finding values of a permanent character in the function of financial support of the political party.

It is a normal characteristic of any organization that its services have utility, either of a collective or an individual nature, which justifies the attribution of a value to it, namely, a market value to be measured by a certain price. Without its utility, the existing organization would terminate its function because of the lack of financial support. The existence of utility in politics provides for the offspring of political organizations, as an answer to necessity and opportunity. The political party is an organization that performs a relevant social service. Its candidacy for the leadership of the social system requires it to be a complex organization of services. The social status of such services is obviously not perfectly clarified. This nebulous question drives the political party into the search for serious solutions for its political problems, where 
originality and secrecy go hand in hand, but leaves behind many concerns about its methods and intentions.

If the question of financing the political party is understood as a payment for the function of representation, it is expected that the direct contribution of its members would suffice. Apparently, each voter would be interested in showing adherence to a certain political party, maximizing its efficiency in the performance of that duty. Much in the same way, it is reasonable to expect that each member of the political party would be interested in showing gratitude through regular contributions. However, this does not happen. Instead, direct contributions have proved insufficient to the functioning of the political party, and it has become clear that the functions of representation and of expression are not socially recognized as services worthy of payment. In the social market the political service has an undefinable structure, and it seems to be understood as a self-gratifying service that should be a payment in itself. Implicitly, we recognize that the political service is a service of political agents rendered to themselves, through the personal satisfaction given to them by power or the expectation of its exercise. The financial sacrifice would be therefore associated with the satisfaction offered by the attainment of political power, translated into 
dedication to the collective interest of society. Still, these rationalizations do not explain how political agents are expected to survive monetarily.

The patrimonial autonomy attributed to the political activity is a sign of other times, in direct contradiction with the organizational needs of the contemporary political party. If the functioning of the political party is dependent on covert ways of financing it, it must be admitted that this blessing expects a specific counterpart. There is no guarantee that the counterpart does not include the compromising of the political conception of the party and its future exercise of power. There is no reason for surprises when, unexpectedly, the political party becomes more flexible in its positions or even undergoes a profound revision of its political conceptions as a result of financial difficulties. It would not be surprising to find out that party members spontaneously changed their conceptions and perspectives of the political situations at hand, when at stake are their functions and the financial support of their activities.

Although without a clear status in the market, political service is not different from the relations of production as socially defined. This is a paradox for all democratic societies. We do not find any social hesitation 
in paying the services of a doctor or a cook. At the same time, it is not among our social habits to pay for the services of the political party without complexity and, artificiality. The political party is entrusted with the task of creating the conditions to exercise a complex activity; if there ever was a specialist to whom it is essential to ensure independence and autonomy, that certainly is the politician.

Politics is still a delegation of power, and the exercise of politics is a conception that does not justify any regular and specific payment. The politician is an intermediary between the power and the people; he is to be rewarded if a winner.

In a modern society characterized by a mass electorate and a space of action demanding political parties with complex organizations and qualified labor, very little of this makes sense. To insist on diffuse images or covert procedures can contribute to maintaining the mystery, undoubtedly intriguing, concerning the way of life of politicians. Alternatively, it may restrict the right of participating in politics to the wealthy. Silence is not an adequate solution for practices of doubtful legitimacy. 
CONCLUSION

In this thesis an attempt has been made to construct a model of a multi-party system conceived in order to detect the main characteristics and to follow the evolution of a specific subject: the political party. The diversity of problems at the origin of the concept of political party and in the relations established within the political system justifies per se the existence of this study.

The model presented attempts to interpret the concept of political party as comprising a diversity of factors that cannot be captured within the framework of a categoric definition. Functional procedure and organizational structure are just some of the factors that are inserted in a social and political context of interrelations. The perceiving of political phenomena as a system of relations where society and the political system, with all their procedural and structural problems, interrelate to achieve a still higher understanding of the political party microcosms is an interesting idea. This is a study that points toward many conclusions and yet it should not be perceived as leading to a rigid schema, for no unique revelation or final ditactum was achieved. 


\section{BIBLIOGRAPHY}

\section{A. BOOKS}

Almond, Gabriel and sidney Verba. The civic culture: political Attitudes and Democracy in Five Nations. New Jersey: Princeton University, 1963.

Barata, Antonio Soares. Estudos de Ciencias Sociais [studies in Social sciences], 2nd edition. Porto: Porto Editora, 1976.

Caldeira, Arlindo. o Partido de Salazar, Antecedentes organização e Funções da União Nacional [Salazar's Party, Antecedents, Organization and Functions in the National Union (1926-1934)]. Lisbon: Analise Social, 1986.

Fernando, Luis. A União Nacional Reflexões sobre a organização Nacionalista que serviu de suporte ao Estado Novo [The National Union Considerations on the Nationalist organization that supported the New States]. Lisbon: Instituto Superior de Ciencias Socias e Politicas, 1985.

Foucalt, Michel. The Eye of Power. Translated by Mark Seem. New York: Semiotext, 1978.

- The Subject and Power. Edited by Brian Wallis. Art After Modernism: Rethinking Representation. New York: New Museum of Contemporary Art, 1984.

Guedes, Armando M. Marques. Ideologias e Sistemas Politicos [Ideologies and Political Systems]. Lisbon: Instituto de Altos Estudos Militares, 1976.

Judice, José Miguel. Portugal a Deriva [Portugal Drifting]. Lisbon: Edições Tempo, 1978 .

- Futuro Presente [Future Present]. Lisbon: Edições Templo, 1980 .

Lopes, Joaquim Manuel Garcia. Portugal e os Politicos [Portugal and the Politicians]. Porto: Nova Barca, 1978 .

Lopes, Pedro Santana and Jose Duráo Barroso. Sistema de Governo e Sistema Partidário [Governmental system and 
Party System], 1st edition. Lisbon: Livraria Bertrand, 1986.

Louis, Althusser. Lenin and Philosophy and other Essays. Translated by Ben Brewster. London: New Left Books, 1971.

Lowenstein, Karl. Teoria de la Constitucion [Constitutional Theory]. Madrid: Madrid 112 .

Moreira, Adriano. Ciencia Politica [Political Science] Lisbon: Livraria Bertrand, 1979.

- Notas sobre o segredo de Estado em Estudos Politicos e sociais [Notes on the secret of state in Political and Social studies]. Iisbon: Instituto Superior de Ciencias Sociais e Politicas, 1986.

Sartori, Giovanny. Party and Party Systems. London: Cambridge University Press, 1976.

Schumpeter, Joseph. Capitalism, Socialism and Democracy. New York: Harper and Brothers, 1942.

Sousa, Marcelo Rebelo de. Estudos sobre a Constituição [Studies in the Constitution]. Lisbon: Petrony, 1978.

- Estudos de Direito Constitucional [Studies of Constitutional Law], 2nd edition. Lisbon: Faculdade de Dto da Universidade de Lisboa, 1980.

\section{B. THESES AND UNPUBLISHED MATERIAL}

Almeida, José Matias de. "Mudança no Sistema Politico Portugues" [Changes in the Portuguese Political System]. M.A. Thesis, Universidade Tecnica de Lisboa, Lisbon, 1980.

Azevedo, Hermano da Silva. Estudos Politicos [Political studies], 1st draft. Lisbon, 1987.

Nunes, Joao Polibio. "Constitucionalidade politica em Portugal do Pós Abril" [Political constitutionality in Portugal of Post-April]. M.A. Thesis, Universidade Catolica Portuguesa, Lisbon, 1981. 
C. NEWSPAPER ARTICLES

Lourenço, Maria G. "Concepçōes Diferentes de Sociedade separam Freitas de Pintasilgo" [Different conceptions of society separate Freitas from Pintasilgo]. Diário de Noticias (Lisbon), 27 December 1985, p. 11 .

Morgado, José. "As eleições, a cDU e a Doutrina da Bipolarização" [The Election, the CDU and the Doctrine of Bipolarization] (Lisbon), 26 June 1987, p. 7. 